\title{
Andrographolide Induces Autophagic Cell Death and Inhibits Invasion and Metastasis of Human Osteosarcoma Cells in An Autophagy-Dependent Manner
}

\author{
Ying Liua,b Yan Zhang ${ }^{\mathrm{a}}$ Jilong Zou ${ }^{\mathrm{c}}$ Lixin Yan ${ }^{\mathrm{a}, \mathrm{b}}$ Xiufeng Yua,b,d Peng Lu ${ }^{\mathrm{e}}$ \\ Xiaomeng Wu ${ }^{f}$ Qiaozhi Lig Rui Gua,b Daling Zhua ${ }^{a, b}$ \\ aDepartment of Biopharmaceutical Key Laboratory of Heilongjiang Province, Harbin Medical \\ University, Harbin, Heilongjiang Province, ${ }^{b}$ Department of Biopharmaceutical Sciences, Harbin Medical \\ University, Daqing, Heilongjiang Province, 'Department of Orthopaedics, the First Affiliated Hospital \\ of Harbin Medical University, Harbin, Heilongjiang Province, ${ }^{\mathrm{d} C}$ College of Medical Laboratory Science \\ and Technology, Harbin Medical University(Daqing), Daqing, Heilongjiang Province, eDepartment of \\ Orthopaedics, Baoquanling Central Hospital, Baoquanling, Heilongjiang, fDepartment of Pharmacy, \\ the 2nd Affiliated Hospital of Mudanjiang Medical University, Mudanjiang, Heilongjiang Province, \\ 'Department of Pharmaceutical Analysis and Analytical Chemistry, College of Pharmacy, Harbin \\ Medical University, Harbin, Heilongjiang Province, P.R. China
}

\section{Key Words}

Andrographolide $\bullet$ Autophagy $•$ Apoptosis $•$ Epithelial-mesenchymal transition $•$ Osteosarcoma

\begin{abstract}
Background/Aims: Osteosarcoma (OS) is the most common primary malignant tumor of bone tissue. Although treatment effectiveness has improved, the OS survival rate has fluctuated in recent years. Andrographolide (AG) has been reported to have antitumor activity against a variety of tumors. Our aim was to investigate the effects and potential mechanisms of AG in human osteosarcoma. Methods: Cell viability and morphological changes were assessed by MTT and live/dead assays. Apoptosis was detected using Annexin V-FITC/PI double staining, DAPI, and caspase-3 assays. Autophagy was detected with mRFP-GFP-LC3 adenovirus transfection and western blot. Cell migration and invasion were detected by wound healing assay and Transwell ${ }^{\circledR}$ experiments. Results: AG dose-dependently reduced the viability of osteosarcoma cells. No increase in apoptosis was detected in AG-treated human OS MG63 and U-2OS cells, and the pan-caspase inhibitor Z-VAD did not attenuate AG-induced cell death. However, AG induced autophagy by suppressing PI3K/Akt/mTOR and enhancing JNK signaling pathways. 3-MA and Beclin-1 siRNA could reverse the cytotoxic effects of AG. In addition, AG inhibited the invasion and metastasis of OS, and this effect could be reversed with Beclin-1 siRNA. Conclusion: AG inhibits viability and induces autophagic death in OS cells. AG-induced autophagy inhibits the invasion and metastasis of OS.




\section{Introduction}

Osteosarcoma (OS) is characterized by high malignancy rates, poor prognosis, and early lung metastasis [1]. It is the most common primary malignant bone tumor affecting humans. At present, treatment of OS is comprehensive and includes preoperative and postoperative chemotherapy, and surgical treatment [2]. Although the effectiveness of treatment has improved significantly, the osteosarcoma survival rate has fluctuated in recent years, especially with the occurrence of lung metastasis and chemotherapy resistance [3]. Therefore, it is necessary to develop novel therapeutic agents and strategies.

It is well known that plants are a natural treasury of medicines for chemotherapy, and plant extracts have been extensively applied to clinical treatment. Andrographolide (AG, see Fig. 1), a diterpenoid lactone isolated from Andrographis paniculata, has a broad range of pharmacological effects [4]. Previously, pharmacological studies of andrographolide focused on antibacterial, anti-inflammatory, and antiviral activities [5-7]; in recent years, significant progress has been made in the study of the antitumor and immunoregulatory effects of AG, and a remarkable antitumor effect has been shown. AG has been reported to inhibit the proliferation of various different tumor cells by inducing apoptosis [8]. Meanwhile, AG can also inhibit the invasion and metastasis of tumors by inhibiting the expression of matrix metalloproteinase (MMP)2 and MMP9 $[9,10]$. In addition, AG can also increase the sensitivity of cancer cells to chemotherapeutic drugs [11]. However, the role of AG in osteosarcoma remains unknown.

PI3K (phosphatidylinositol 3-kinases) is a lipid kinase, which catalyses the phosphatidylinositol 4,5- two phosphate (PIP2) phosphorylation of phosphatidylinositol three 3,4,5- phosphate (PIP3), then activating AKT (protein kinase B) to promote cell survival, proliferation, metastasis and angiogenesis [12]. PI3K is highly expressed in most malignant tumors, and the study of its inhibitors has attracted widespread attention in the medical community.

Autophagy is a catabolic process that degrades and processes damaged organelles and macromolecules via lysosomal pathways to maintain cellular homeostasis [13]. This process is closely related to many diseases, including cancer [14]. Autophagy may play opposing roles in different stages of tumor development and in different tumors, including promoting survival and inducing death [15]. Therefore, research into the molecular mechanisms of autophagy-related signal transduction pathways, such as those involving PI3K/Akt/mTOR [16], MAPK [17], ROS [18], and NF-kB [19], is of great importance. Recent studies have implied that autophagy is associated with tumor invasion and metastasis. Catalano et al [20]. showed that autophagy could reverse epithelial-mesenchymal transition (EMT) and inhibit migration and invasion in glioblastoma, and this was corroborated in neuroblastoma cells [21]. However, there are no reports to support a relationship between AG and EMT in osteosarcoma.

Therefore, for the first time, we investigated the effects of AG on apoptosis and autophagy in osteosarcoma cells and the underlying mechanisms. Moreover, we hypothesized that autophagy induced by AG may inhibit the invasion and migration of osteosarcoma by participating in the regulation of EMT.

\section{Materials and Methods}

\section{Materials}

Andrographolide and Dihydroartemisinin was purchased from Yuanye Biotechnology Co. Ltd (Shanghai,China). PI3K Class I, PI3K Class III E-cadherin, Snail, p-mTOR, mTOR, p-ERK, ERK and $\beta$-actin antibodies were purchased from Santa cruz Biotechnology (Santa cruz, CA, USA). Vimentin, N-cadherin, Atg5 and Beclin-1 antibodies were obtained from Boster Biological Technology Co. Ltd (Wuhan, China). U0126, SP600125, p-Akt, Akt, p-JNK, JNK, p-p38 and p38 antibodies were obtained from Beyotime Institute of Biotechnology (Haimen, China). Antibody against LC3B was purchased from Abcam (Cambridge, UK). All other reagents were from common commercial sources.

\section{KARGER}




\section{Cellular Physiology Cell Physiol Biochem 2017;44:1396-1410

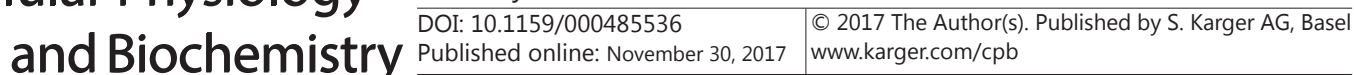

Liu et al.: Andrographolide Induces Autophagy in Osteosarcoma Cells

\section{Cell culture}

Osteosarcoma cells (U-2OS, MG-63 and SaOS-2) were obtained from Qiaodu Biotechnology Co. Ltd (Shanghai, China). U-2OS and SaOS-2 cells were cultured in McCoy's 5A (Sigma, M4892) with 10\% fetal bovine serum (CLARK, FB25015), MG-63 cells were cultured in MEM (Gibco 41500-034) with 10\% fetal bovine serum, penicillin $(100 \mathrm{U} / \mathrm{mL})$ and streptomycin $(100 \mathrm{U} / \mathrm{mL}$ ) in a humidified incubator (Thermo Fisher, Runcorn, Cheshire, UK) with $5 \% \mathrm{CO}_{2}$ at $37^{\circ} \mathrm{C}[22,23]$.

\section{MTT Assay}

The effects of Andrographolide on osteosarcoma cells were analysed by MTT assays. Briefly, the cells were seeded in 96-well plates at a density of $1 \times 10^{4}$ cells per well. After a $24 \mathrm{~h}$ incubation, the cells were subjected to different treatments. Following the treatment, cells were incubated with $0.5 \%$ MTT in medium at $37^{\circ} \mathrm{C}$ for 4 hours. The reaction was terminated by removing the supernatant, adding dimethyl sulfoxide $(150 \mu \mathrm{l} /$ well), and shaking for $10 \mathrm{~min}$ at room temperature. The absorbance was measured at $490 \mathrm{~nm}$ in a spectrophotometer [22].

\section{Clonogenic assay}

Single-cell suspensions were prepared for each cell line and specific numbers of cells were seeded in six-well tissue culture plates. Then cells were exposed to various concentrations of Andrographolide for 2 weeks. Finally, the media were carefully removed by aspiration. Colonies were stained by crystal violet, photographed, and scored [24].

Caspase-3 activity

Caspase-3 activity was measured using a colorimetric assay kit (Biovision) according to the manufacturer's instructions. Samples were read at $405 \mathrm{~nm}$ in a microplate reader (Bio-Tek Instruments) [25].

\section{Flow cytometry}

Annexin V-FITC/PI double staining was used to confirm the apoptotic effect on cells, and the samples were analyzed by a flow cytometer (Becton Dickinson) using FACSDiva ${ }^{\mathrm{TM}}$ software [26].

\section{Beclin 1 siRNA transfection}

Cells were seeded in 6-well plates and incubated for 24 hours, then transfected with beclin 1-targeted

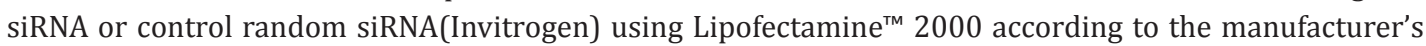
protocol. At 24 hours after transfection, cells were treated with or without AG for additional 24 hours and collected for western blot. Transfected cells were also used for MTT, Immunocytochemistry, Live/dead assay, Wound healing assay, Migration and invasion assays [23].

\section{Live/dead assay}

The assay was performed using a LIVE/DEAD® Viability/Cytotoxicity Assay Kit (Invitrogen). MG-63 cells were subjected to different treatments. Then, the cells were washed twice with phosphate buffered saline (PBS) and were incubated for another $30 \mathrm{~min}$ at $37^{\circ} \mathrm{C}$; the cells were protected from light with DMEM solution containing $2.5 \mu \mathrm{M}$ calcein AM and $4 \mu \mathrm{M}$ ethidium homodimer-1 (EthD-1). Finally, the results were observed using fluorescence microscopy (Olympus) [27].

\section{Wound healing assay}

The confluent U-2OS cells cultured in six-well plates were wounded by yellow tip, cells were received various treatments for $0,12,24,48 \mathrm{~h}$, and they were examined under an inverted microscope (Nikon) [22].

\section{Migration and invasion assays}

U-2OS cells were incubated with different groups prior to migration and invasion assays. The migration assay was performed using a modified Boyden chamber. McCoy's 5A with 10\% FBS was in the lower layer of the transwell. Resuspended U-20S cells in McCoy's 5A without FBS were added into the upper chamber. The cells in the 8- $\mu \mathrm{m}$-pore polycarbonate filter were fixed with $4 \%$ paraformaldehyde, and stained with $0.4 \%$ crystal violet. Cells in the upper of the filter were removed, and the number of stained migrated cells 


\section{Cellular Physiology Cell Physiol Biochem 2017;44:1396-1410

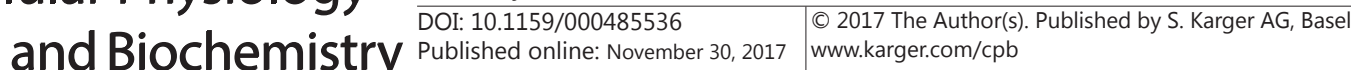

was counted under an inverted microscope (Nikon). The invasion assay was also performed using a modified Boyden chamber. Matrigel (BD Biosciences) was diluted with cold filtered distilled water to receive the concentration $25 \mu \mathrm{g} / 50 \mu \mathrm{L}$ and applied to the upper to $8 \mu \mathrm{m}$ pore size polycarbonate membrane filters of the upper well. The cells treated with different groups were measured as described in the cell migration assay [23].

\section{Western Blotting}

Proteins were extracted with cold lysis buffer. Following centrifugation, the supernatant was harvested. Subsequently, $20 \mu \mathrm{g}$ protein samples were electrophoresed on $6 \% \sim 12 \%$ SDS-PAGE, and transferred onto nitrocellulose membrane (Millipore, USA). After blocked with $5 \%$ nonfat milk in Tris-buffered saline buffer $(20 \mathrm{mM}$ Tris, $150 \mathrm{mM} \mathrm{NaCl}, \mathrm{pH} 7.6$, Tween20 0.1\%), the membranes were incubated with primary antibodies at $4^{\circ} \mathrm{C}$ overnight, and reacted with horseradish peroxidase-conjugated secondary antibodies. Blot bands were developed by enhanced chemiluminescence reagents (Amersham, UK). PI3K Class I, PI3K Class III, E-cadherin, Snail, p-mTOR, mTOR, p-ERK, ERK and $\beta$-actin antibodies were purchased from Santa cruz Biotechnology (Santa cruz, CA, USA). Vimentin, N-cadherin, Atg5 and Beclin-1 antibodies were obtained from Boster Biological Technology Co. Ltd (Wuhan, China). U0126, SP600125, p-Akt, Akt, p-JNK, JNK, p-p38 and p38 antibodies were obtained from Beyotime Institute of Biotechnology (Haimen, China). Antibody against LC3B was purchased from Abcam (Cambridge, UK).

\section{Immunocytochemistry}

Prepared cells were fixed with $4 \%$ paraformaldehyde for $15 \mathrm{~min}$, permeabilized with $0.5 \%$ Triton $\mathrm{X}-100$ for $10 \mathrm{~min}$, and blocked with $5 \%$ normal bovine serum for $30 \mathrm{~min}$. After that, samples were incubated with antibodies at $4{ }^{\circ} \mathrm{C}$ overnight. Then secondary antibody (Cy3 or FITC) was incubated for $1 \mathrm{~h}$ in dark, and DAPI was counterstained for $5 \mathrm{~min}$. Samples were examined with a fluorescence microscope (Nikon) [27].

\section{Evaluation of fluorescent LC3 puncta}

LC3 puncta were indicated by mRFP-GFP-LC3 adenovirus (Hanbio Co., LTD, China). Briefly, cells were transfected with mRFP-GFP-LC3 for $24 \mathrm{~h}$ before receiving Andrographolide treatments. After 24-hours Andrographolide $(60 \mu \mathrm{M})$ treatment, cells were observed under a confocal fluorescence microscopy (Nikon). Autophagic cells, which contained five or more mRFP-GFP-LC3 dots were recorded and the images were acquired [28].

\section{Statistical analysis}

The values were presented as Mean \pm SD. Statistical analysis between different groups were performed with one-way or two-way ANOVA, followed by Dunnett's test or Student's t-test. $p<0.05$ was considered statistically significant.

\section{Results}

$A G$ inhibits the proliferation of MG-63, U-20S, and SaOS-2 cells

The cytotoxicity of AG to different human osteosarcoma cell lines was confirmed by MTT assay. As shown in Fig. 2A and 2B, cell viability was reduced in a dose-dependent manner after exposure to various concentrations of $\operatorname{AG}(0,3,15,30$, and $60 \mu \mathrm{M})$ for $24 \mathrm{~h}$ and $48 \mathrm{~h}$. The growth-inhibitory effects of AG on OS cells were further examined by clonogenic assay. As shown in Fig. 2C and 2D, the colony-forming abilities of MG-63 and U-20S cells were greatly inhibited by AG in a dose-dependent manner. Because cell death may be due to apoptosis or autophagy, we explored the effects of an apoptosis inhibitor (z-VAD) and an autophagy inhibitor (3-MA) on AG-induced cell death. MG-63 and U-20S cells were treated 


\section{Cellular Physiology Cell Physiol Biochem 2017;44:1396-1410 \begin{tabular}{l|l|l} 
DOI: 10.1159/000485536 & O 2017 The Author(s). Published by S. Karger AG, Basel \\
www.karger.com/cpb
\end{tabular}}

Liu et al.: Andrographolide Induces Autophagy in Osteosarcoma Cells

with $60 \mu \mathrm{M}$ AG for $24 \mathrm{~h}$ in the presence of $2 \mathrm{mM}$ 3-MA. As shown in Fig. 2E and 2F, 3-MA significantly attenuated AG-induced cytotoxicity in MG-63 and U-20S cells. In contrast, the caspase inhibitor z-VAD failed to reverse AG-induced cytotoxicity.

\section{AG-induced cell death in OS cells is not due to apoptosis}

AG has been reported to induce apoptosis in some cancer cells $[8,29,30]$, and we investigated whether AG could induce apoptosis in OS cells. Contrary to our expectation, as shown in Fig. 3A, DAPI staining did not show nuclear condensation in MG-63 or U-20S cells after AG treatment compared with DHA-treated cells. Caspase-3 is a major regulator of apoptosis [31].This finding was further confirmed by caspase-3 activity analysis (Figure 3B). In addition, annexin-V/PI double staining assessed using flow cytometry showed no significant increase in the percentage of AG-treated OS cells (Figure 3C and 3D). These data indicate that AG does not induce apoptosis in MG-63 and U-20S cells.

\section{AG induces autophagic cell death in OS cells}

We measured the expression of LC3II, Beclin-1, and autophagy related 5 (Atg5), which are recognized as classical autophagy-related markers [32], and observed a dose-dependent increase in expression level with AG treatment in MG-63 and U-20S cell lines (Fig. 4A and 4B). To confirm autophagy in OS cells, we used mRFP-GFP-LC3 fluorescence to detect autophagosomes. As shown in Fig. 4F, AG induced a massive flux of autophagy, with a large number of autophagosomes (yellow) and autolysosomes (red) in MG-63 and U-20S cells. Beclin- 1 is an essential molecule that can regulate the initiation and maturation of autophagy [33]. To determine whether the cytotoxicity of AG toward MG-63 and U-20S cells was due to autophagy, we employed Beclin-1 siRNA (Fig. 4G). The results showed that viability of AG-treated cells was significantly increased in Beclin-1 knockdown cell lines (Fig. 4H). The LIVE/DEAD $®$ viability/cytotoxicity assay also produced similar results in MG-63 cells (Fig. 4I). Taken together, these results indicate that AG-induced cell death in osteosarcoma cells is autophagy dependent.

\section{AG induces autophagy by suppressing PI3K/Akt/mTOR signaling pathways}

Autophagy is regulated by a variety of signaling molecules. mTOR functions at the center of various signaling pathways, and the classic PI3K/Akt/mTOR pathway regulates autophagy mainly through the activation of mTOR [34]. PtdIns(3, 4)P2 and PtdIns $(3,4,5)$ P3, produced by class I PI3K, can interact with the pleckstrin homology domain of Akt, activating the Akt signaling pathway, which indirectly activates mTOR to inhibit autophagy [35]. The class III PI3K complex, which contains beclin-1, p150, and Atg14-like protein, or the ultraviolet-irradiation-resistance-associated gene, is required for the induction of autophagy, and is a critical positive regulator of autophagy [36]. To investigate the molecular mechanisms of AG-induced autophagy, class I and class III PI3K expression levels and Akt and mTOR kinase activity, as measured by phosphorylation, were examined using different concentrations of AG. As shown in Fig. 5A and 5B, in AG-treated MG-63 and U-20S cell lines, class I PI3K expression decreased, whereas class III PI3K expression increased. In addition, AG significantly inhibited Akt and mTOR phosphorylation compared with controls. These results suggest that AG may induce autophagy by inhibiting the PI3K/Akt/mTOR pathway.

\section{Activation of the JNK signaling pathway is also involved in AG-induced autophagy}

In addition to the classical PI3K/Akt/mTOR pathway, MAPK signaling (including JNK, ERK, and p38 MAPKs) is also closely involved in the regulation of autophagy [37-39]. Therefore, MAPK signaling was investigated in AG-treated OS cells. In this study, treatment with AG inhibited p38 phosphorylation; however, ERK and JNK phosphorylation expression levels increased in AG-treated cells (Fig. 6A and 6B). To further investigate the effects of upregulation of JNK and ERK during AG-induced autophagy, we used specific inhibitors of ERK (U0126) and JNK (SP600125) in MG-63 and U-20S cells. The data showed that combined treatment with the JNK inhibitor and $60 \mu \mathrm{M}$ AG reduced LC3-II, Beclin-1, and Atg5 expression 
A
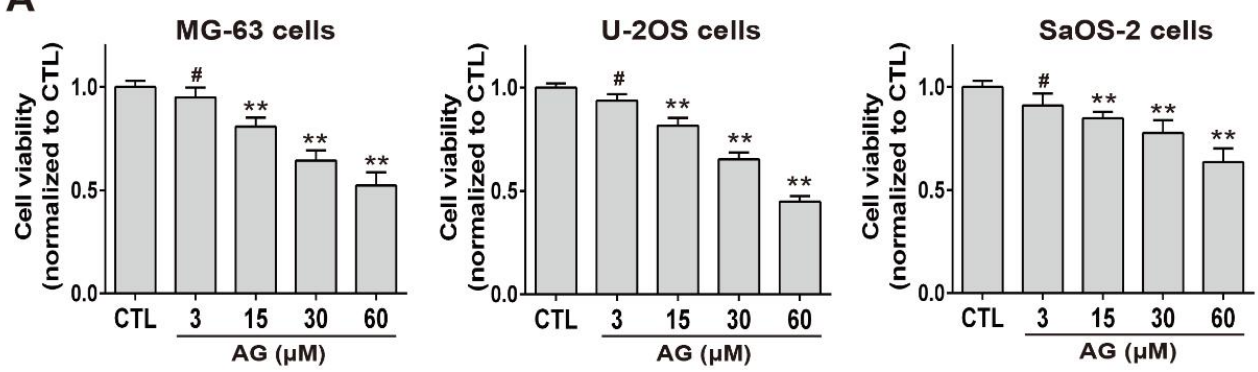

B
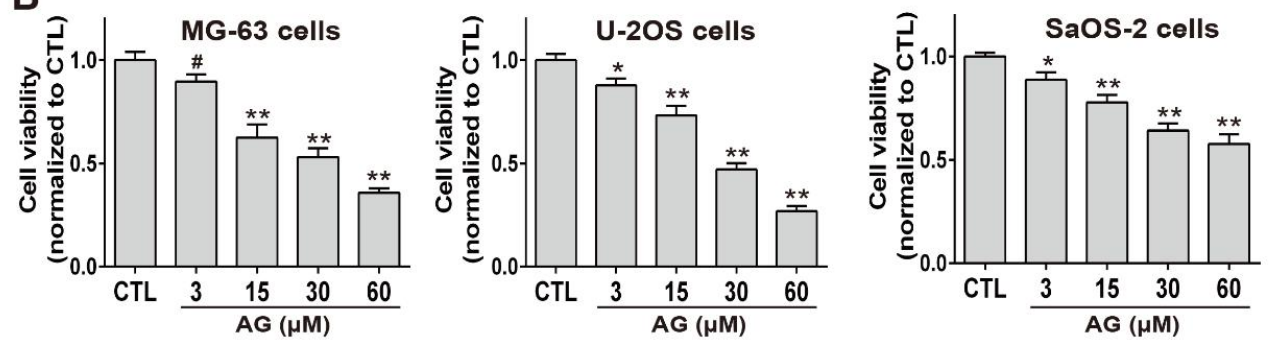

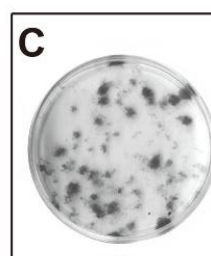

CTL

D

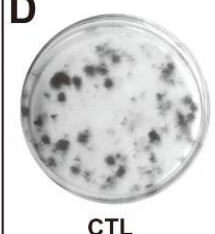

CTL

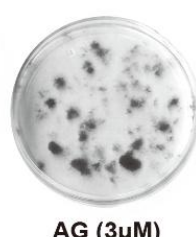

AG $(3 \mu \mathrm{M})$

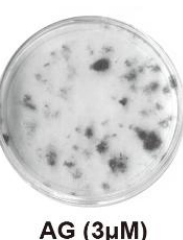

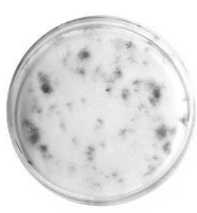

AG $(15 \mu \mathrm{M})$

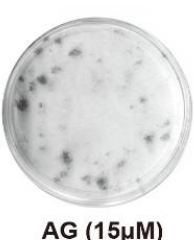

AG $(15 \mu \mathrm{M})$
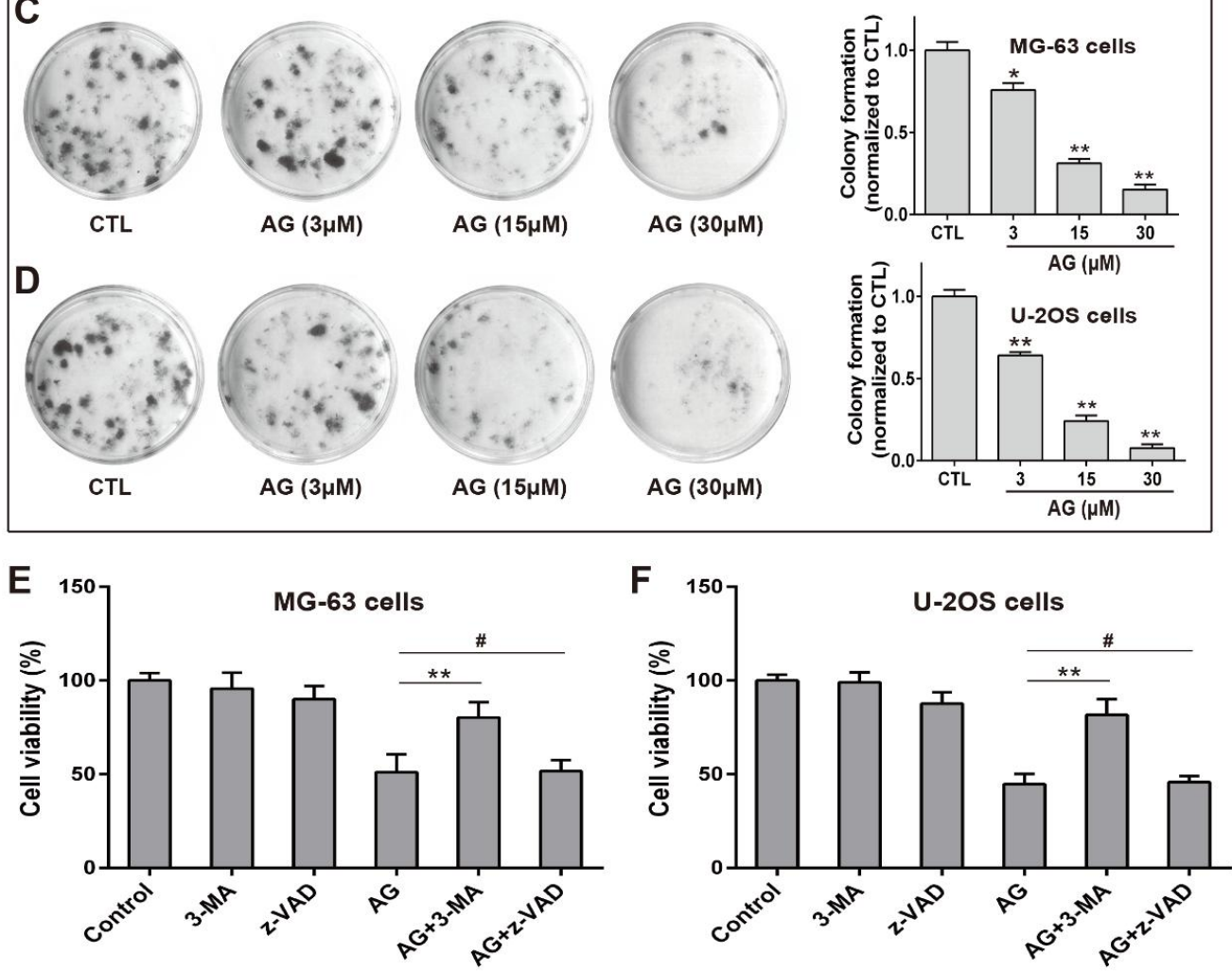

Fig. 2. Andrographolide (AG) reduces the viability of osteosarcoma cells. (A and B) AG dose-dependently reduced the viability of MG-63, U-20S, and SaOS-2 cells after $24 \mathrm{~h}$ and $48 \mathrm{~h}$ treatment $(\mathrm{n}=12) .{ }^{*} \mathrm{P}<0.05$, ${ }^{* *} \mathrm{P}<0.01$ versus CTL. CTL, control. ${ }^{\mathrm{P}}>0.05$. (C and D) Plate clonality assay showing inhibitory effects of AG on MG-63 and U-20S cells. Experiments were performed in triplicate. (E and F) Cell viability was measured by MTT assay in MG-63 and U-20S cells after treatment with $60 \mu \mathrm{M}$ AG for $24 \mathrm{~h}$. The autophagy inhibitor 3-MA (2.0 mM) or caspase inhibitor z-VAD $(0.1 \mathrm{mM})$ were preincubated with cells for $2 \mathrm{~h}$ before the addition of $A G(n=6) . * * P<0.01,{ }^{*} P>0.05$. All data are presented as the mean $\pm S D$.

\section{KARGER}


A
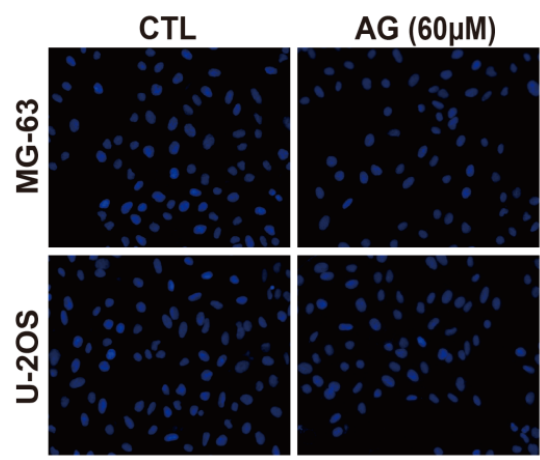

C

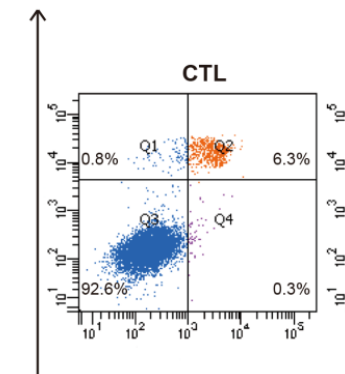

$\bar{a}$

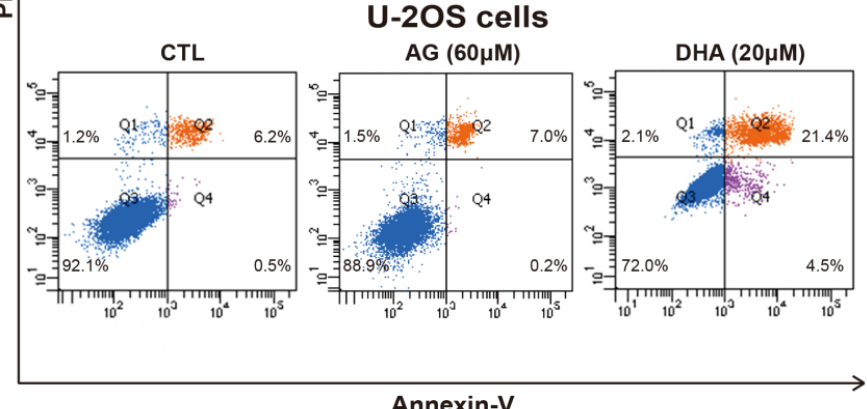

B
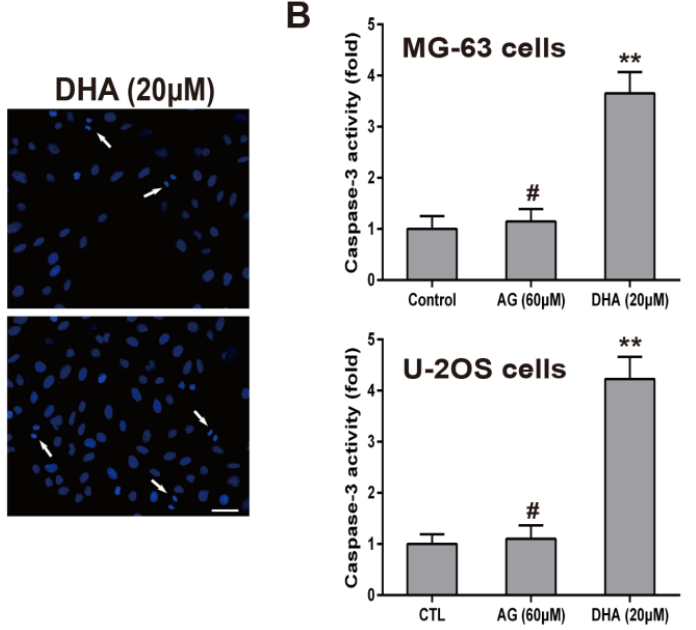

D
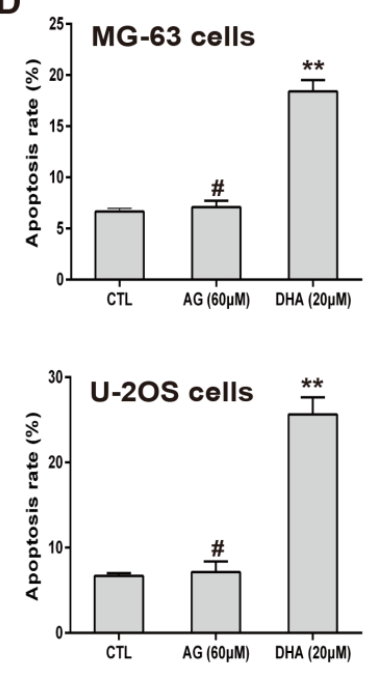

Fig. 3. Andrographolide (AG)-induced cell death is not due to apoptosis in osteosarcoma cells. (A) MG-63 and U-20S cells were treated with $\mathrm{AG}(60 \mu \mathrm{M})$ for $24 \mathrm{~h}$, followed by immunostaining and observation of DAPI staining (blue) by fluorescence microscopy. Dihydroartemisinin (DHA; $20 \mu \mathrm{M}$ )-treated cells served as a positive control; scale bar $=50 \mu \mathrm{m}$. (B) After incubation with AG for $24 \mathrm{~h}$, the cytosolic fractions of MG-63 and U-20S cells were analyzed for changes in the activity of caspase- 3 using a colorimetric assay. (C and D) MG-63 and U-20S cells were treated with AG $(60 \mu \mathrm{M})$ or DHA $(20 \mu \mathrm{M})$ for $24 \mathrm{~h}$. Subsequently, cells were double-stained with Annexin-V and PI and then analyzed by flow cytometry. The DHA group served as a positive control. All data are presented as the mean $\pm \mathrm{SD}(\mathrm{n}=3)$. ${ }^{* *} \mathrm{P}<0.01$ versus CTL. CTL, control. ${ }^{*} \mathrm{P}>0.05$.

compared with AG treatment alone (Fig. 6F and 6G). Conversely, combined treatment with AG and the ERK inhibitor did not affect LC3-II, Beclin-1, and Atg5 expression levels (Fig. 6F and $6 \mathrm{G}$ ). Therefore, the enhancement of JNK signaling pathways may result in AG-induced autophagy.

$A G$-induced autophagy reverses EMT and inhibits invasion and metastasis in U-2OS cells

We suspected that the activation of autophagy by AG was involved in the suppression of EMT in U-2OS cells. When cells were treated with AG and Beclin-1 siRNA, the expression levels of EMT-related marker proteins were reversed compared to those after AG treatment 


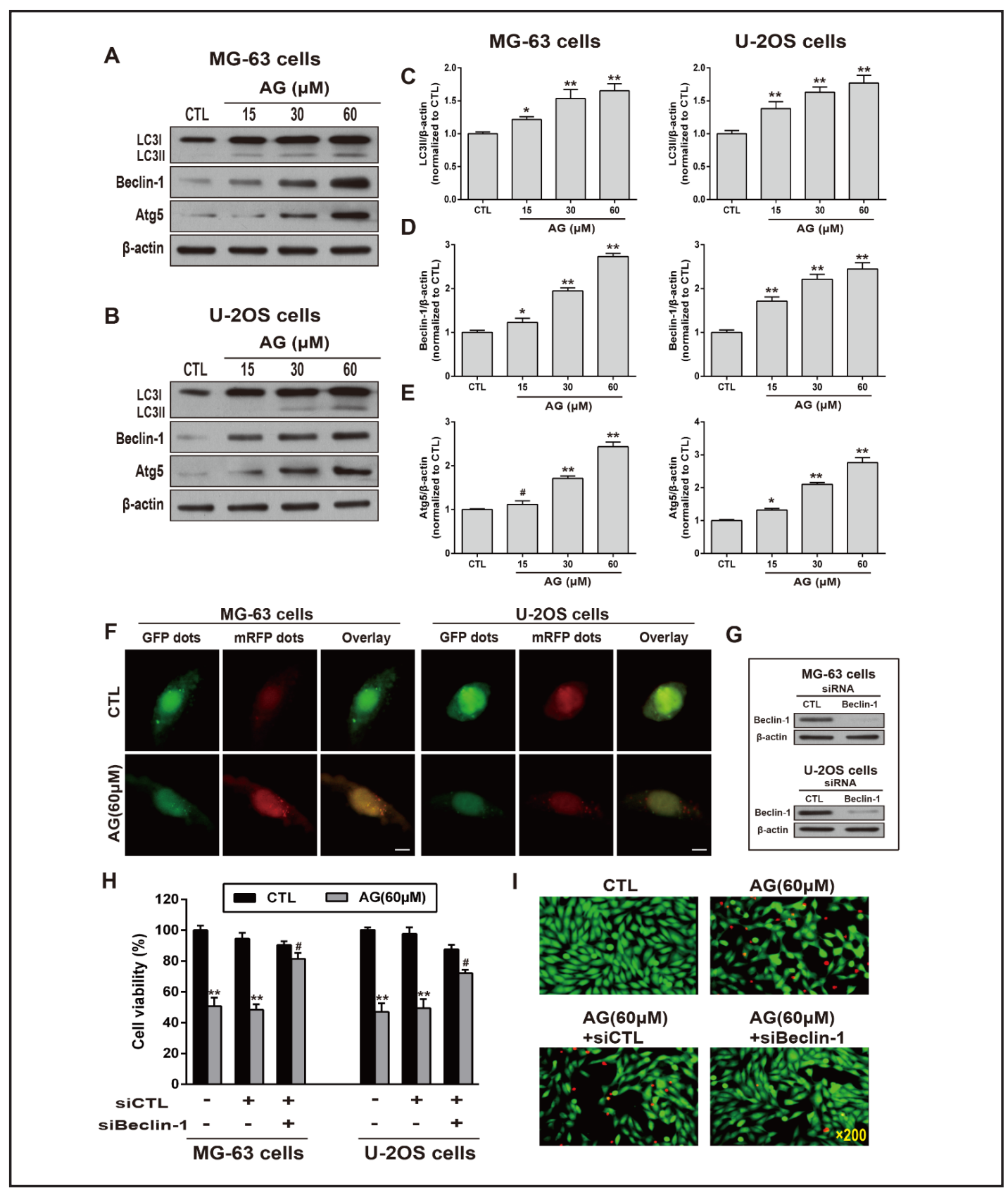

Fig. 4. Andrographolide (AG) induces autophagic cell death in osteosarcoma cells. (A and B) Western blot analysis of the expression of autophagy-related proteins LC3II, Beclin-1, and Atg5 in MG-63 and U-20S cells treated with different concentrations of $\mathrm{AG}(0,15,30$, or $60 \mu \mathrm{M})$. $\beta$-actin served as loading control. Quantification of western blot data for LC3II (C), Beclin-1 (D), and Atg5 (E) in MG-63 and U-20S cells ( $n=3$ ). (F) After $24 \mathrm{~h}$ of AG $(60 \mu \mathrm{M})$ treatment, MG-63 and U-20S cells transfected with mRFP-GFP-LC3 adenovirus were observed under a confocal fluorescence microscope. Representative images are presented to indicate the cellular localization patterns of the mRFP-GFP-LC3 fusion protein; scale bar $=10 \mu \mathrm{m}$. (G) Expression of autophagy gene Beclin-1 was silenced by siRNA in MG-63 and U-20S cells. (H) After transfection with control siRNA or Beclin-1 siRNA, cells were treated with or without AG $(0$ and $60 \mu \mathrm{M})$ for $24 \mathrm{~h}$ and analyzed by MTT assay ( $n=3)$. (I) Beclin-1 siRNA treatment ameliorated AG-induced cell death in MG-63 cells, shown using the LIVE/DEAD staining assay to identify live (green) and dead (red) cells. All data are presented as the mean $\pm \mathrm{SD} .{ }^{*} \mathrm{P}<0.05,{ }^{* *} \mathrm{P}<0.01$ versus CTL. CTL, control. ${ }^{*} \mathrm{P}>0.05$. 


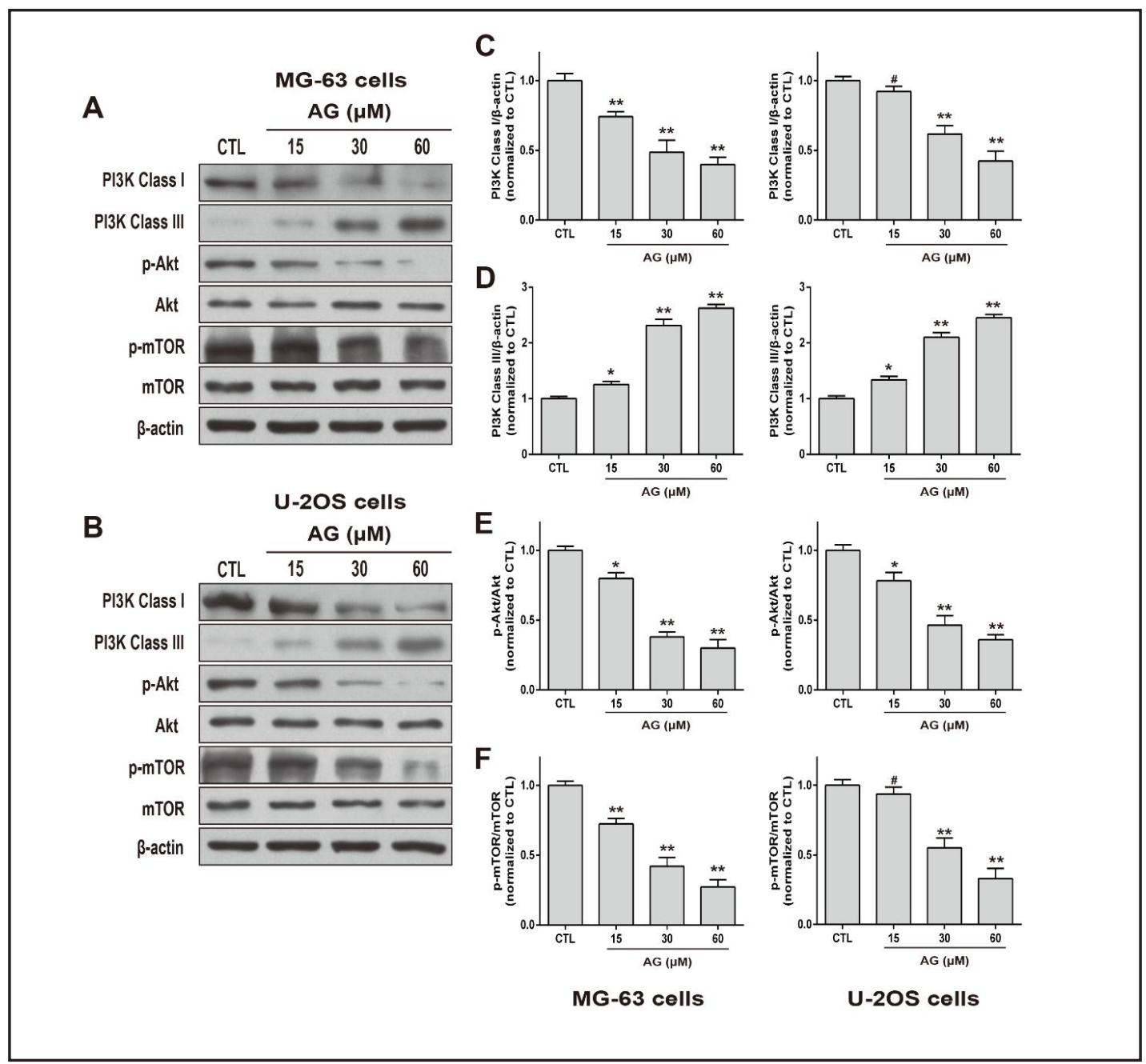

Fig. 5. AG inhibits the PI3K/Akt/mTOR signaling pathway. (A and B) MG-63 and U-2OS cells were treated with $\mathrm{AG}(0,15,30$, or $60 \mu \mathrm{M})$ for $24 \mathrm{~h}$ and then subjected to western blotting for class I PI3K, class III PI3K, Akt, and mTOR with $\beta$-actin as an internal control. (C-F) Expression levels of class I PI3K, class III PI3K, phospho-Akt, and phospho-mTOR were subsequently quantified with that of control. All data are presented as the mean $\pm \mathrm{SD}(\mathrm{n}=3) .{ }^{*} \mathrm{P}<0.05,{ }^{* *} \mathrm{P}<0.01$ versus CTL. CTL, control. ${ }^{*} \mathrm{P}>0.05$, no significance.

alone (Fig. 7A and 7B). A similar trend could be observed by immunofluorescence assay (Fig. 7C). Next, we investigated the effect of AG on cell migration by wound healing assay in U-2OS cells. AG inhibited migration; however, after the addition of Beclin-1 siRNA, this effect was reversed in a time-dependent manner (Fig. 7D and 7E). A Transwell ${ }^{\circledR}$ experiment was performed with U-20S cells to detect both migration and invasion. As shown in Fig. 7F and 7G, AG significantly inhibited both migration and invasion, and this was also reversed by the presence of Beclin-1 siRNA.

\section{Discussion}

AG has been reported to possess antitumor activity in various human cancer cell lines, including lung [40], hepatocellular carcinoma [41], breast [42], and colon [43] cancer cells. In this study, we investigated the antitumor effect of AG on human OS cells for the first time and showed that treatment with AG induces autophagy, but not apoptosis, in human OS 


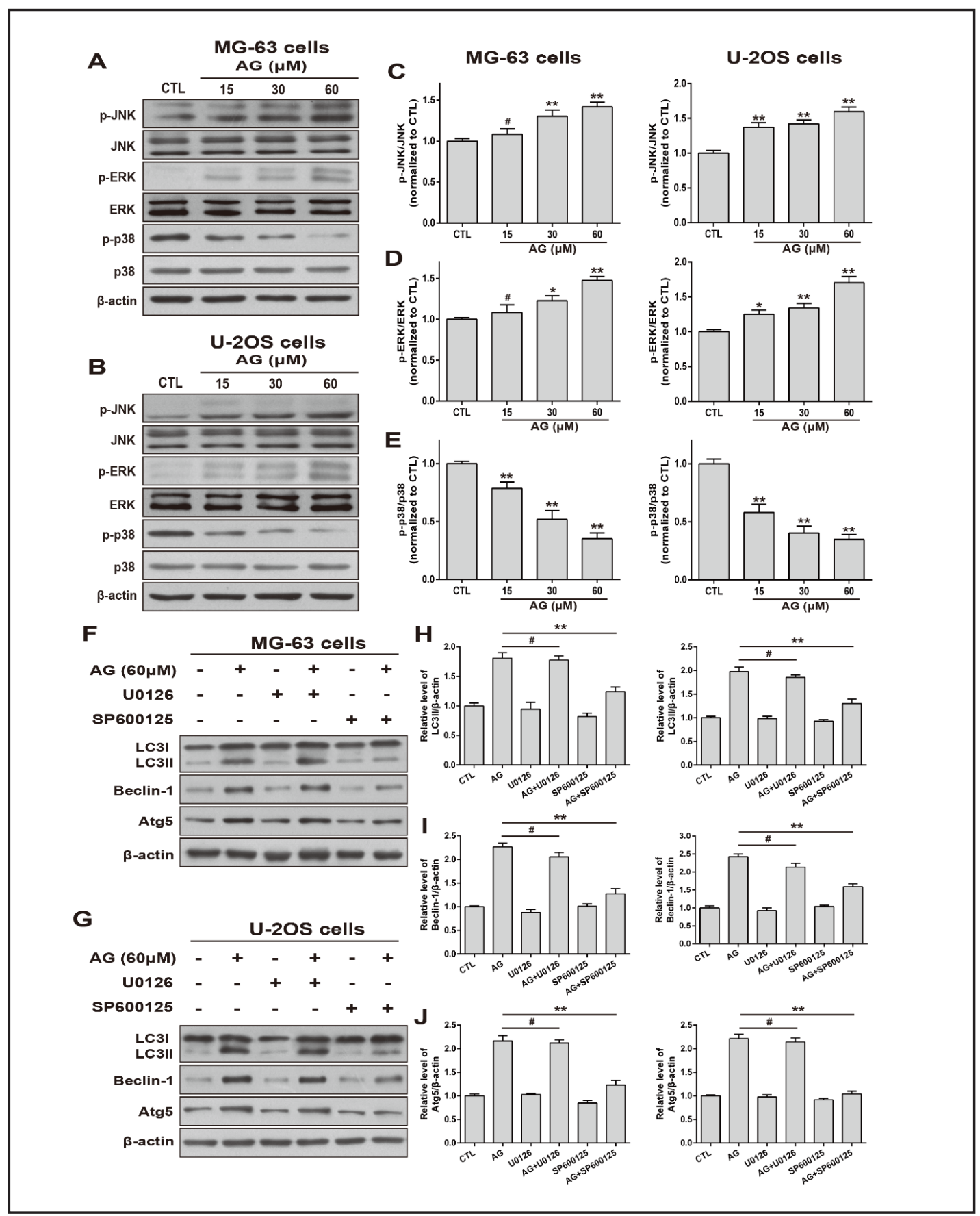

Fig. 6. Effect of MAPK pathway on andrographolide (AG)-induced autophagy processes. (A and B) MG-63 and U-20S cells were treated with $A G(0,15,30$, or $60 \mu \mathrm{M})$ for $24 \mathrm{~h}$ and then subjected to western blotting for JNK, ERK1/2, and p38 with $\beta$-actin as an internal control. (C-E) Expression levels of phospho-JNK, phosphoERK, and phospho-p38 were quantified against that of the control. Results are shown as mean $\pm S E(n=3)$. ${ }^{*} \mathrm{P}<0.05,{ }^{* *} \mathrm{P}<0.01$ versus CTL. CTL, control. ${ }^{*} \mathrm{P}>0.05$. (F-G) MG-63 and U-20S cells were treated with AG (60 $\mu \mathrm{M}$ ) for $24 \mathrm{~h}$ in the presence or absence of specific inhibitors of ERK (U0126) and JNK (SP600125) at $20 \mu \mathrm{M}$ and then subjected to western blotting for LC3II, Beclin-1, and Atg5 with $\beta$-actin as an internal control. (H-J) Expression levels of LC3II, Beclin-1, and Atg5 were quantified against that of the control. Results are shown as mean $\pm \mathrm{SE}$. ${ }^{* *} \mathrm{P}<0.01,{ }^{\#} \mathrm{P}>0.05$. 
A

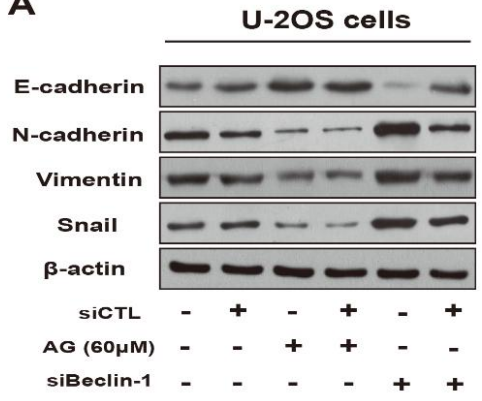

B
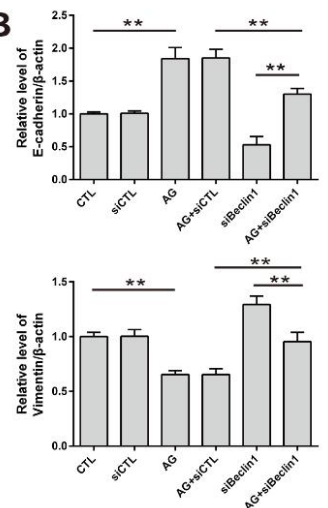
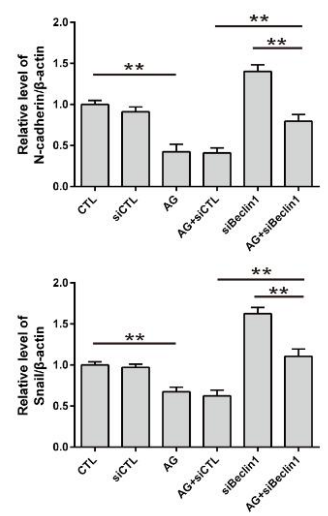

C
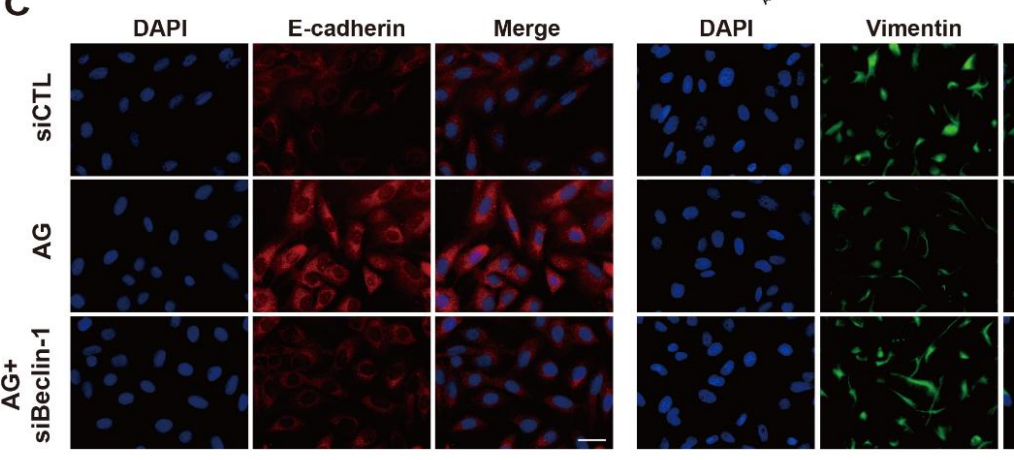

Merge

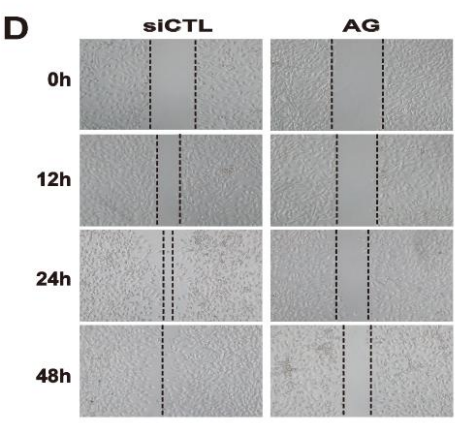

AG

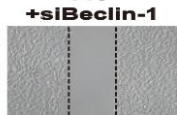

E

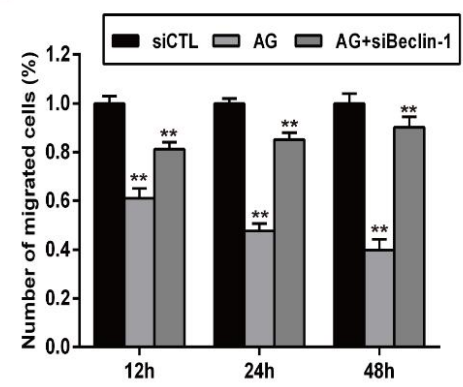

F
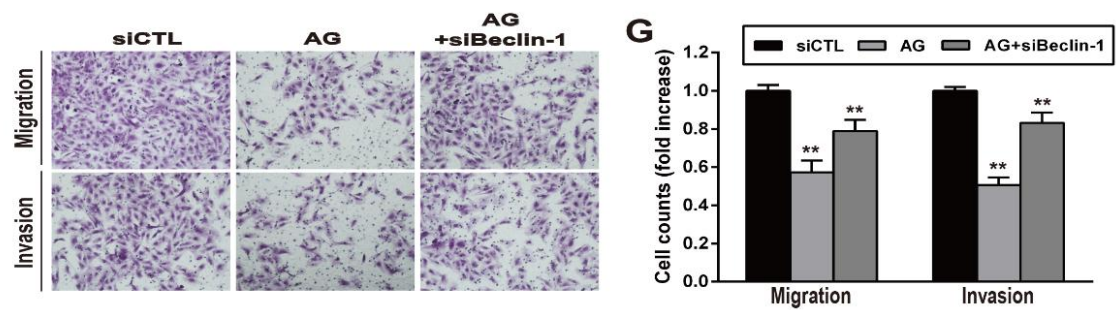

Fig. 7. Andrographolide (AG)-induced autophagy reverses epithelial-mesenchymal transition (EMT) and inhibits invasion and metastasis in U-20S cells. (A) Western blot analysis of the expression of E-cadherin, $\mathrm{N}$-cadherin, vimentin, and Snail proteins in U-20S cells with $\beta$-actin as a loading control. (B), Expression levels of E-cadherin, $\mathrm{N}$-cadherin, vimentin, and Snail were quantified against that of the control. Results are shown as mean $\pm \mathrm{SE}(\mathrm{n}=3) .{ }^{* *} \mathrm{P}<0.01$. CTL, control. (C) Expression of E-cadherin and vimentin in U-20S cells from different treatment groups (siCTL, AG $60 \mu \mathrm{M}$, and AG $60 \mu \mathrm{M}+$ siBeclin-1) assessed by immunofluorescence; scale bar $=50 \mu \mathrm{m}$. (D and E) U-20S cells were wounded and then treated siCTL, AG $60 \mu \mathrm{M}$, or AG $60 \mu \mathrm{M}+$ siBeclin-1 for 12, 24, and $48 \mathrm{~h}$. (F and G) Cell migration was measured using a Boyden chamber with polycarbonate filters for $24 \mathrm{~h}$. Cell invasion was measured using a Matrigel-coated Boyden chamber with polycarbonate filters for $48 \mathrm{~h}$. The bar graph summarizes the results, which are shown as mean $\pm \mathrm{SE}(\mathrm{n}=3) .{ }^{* *} \mathrm{P}<0.01$ versus CTL. CTL, control.

\section{KARGER}




\section{Cellular Physiology Cell Physiol Biochem 2017;44:1396-1410 \begin{tabular}{l|l} 
DOI: 10.1159/000485536 & $\begin{array}{l}\text { O 2017 The Author(s). Published by S. Karger AG, Basel } \\
\text { www.karger.com/cpb }\end{array}$
\end{tabular}}

Liu et al.: Andrographolide Induces Autophagy in Osteosarcoma Cells

cells. AG has been shown to induce apoptosis in a variety of cancers; however, we did not detect any increased apoptosis signal (with DAPI or caspase-3 assay) in AG-treated human OS MG-63 and U-20S cells. The pan-caspase inhibitor z-VAD did not attenuate AG-induced cell death. Taken together, these results indicate that AG-induced cell death does not occur via caspase-dependent apoptosis in these cells.

Autophagy, or type II programmed cell death, is a process by which subcellular constituents are degraded in autophagosomes/autolysosomes in response to stress [13]. The significance of autophagy in antitumor therapeutics has not been clearly elucidated, although autophagy promotes the survival of cancer cells during malnutrition and hypoxia. That is, the degradation of intracellular proteins and organelles provides nutrients and energy for tumor cell growth, facilitating the survival of tumor cells in poor environments [44]. In addition, autophagy may protect tumor cells from cancer treatment by removing damaged organelles, allowing cells to escape apoptosis and continue to survive [45]. On the other hand, when autophagy capacity is decreased, cell proliferation can increase and promote tumor formation [46]; moreover, when cells are in a stressed state, levels of DNA and protein damage depend on the removal or repair ability of autophagy to maintain cellular homeostasis. If autophagy capacity is reduced, DNA damage that occurs can cause cancer [47]. Whether autophagy triggered by AG in OS cells is a survival mechanism or a cell death mechanism was elucidated in this study by applying 3-MA, a chemical inhibitor of autophagy. Our results indicated that 3-MA could reverse the cytotoxic effect of AG, suggesting that AG induces autophagic cell death. These findings were further validated by silencing Beclin-1, a key molecule involved in autophagosome formation and maturity [48].

Autophagy is a multifaceted process, and alterations in autophagic signaling pathways are frequently observed in cancer [49]. Akt and mTOR phosphorylation decreased in a manner that correlated with AG treatment. In addition, AG specifically inhibited class I PI3K expression and increased class III PI3K expression. 3-MA is an inhibitor of PI3K that blocks autophagy at an early stage; this occurs by inhibiting class III PI3K expression and thereby blocking autophagosome formation [50]. These results reveal that AG induces autophagic cell death in OS cells by inhibiting the PI3K/Akt/mTOR pathway. Previous studies have shown that autophagy is activated by multiple pathways, including JNK [37] and ERK [38]. Our data suggest that AG induces autophagy by activating JNK but not ERK. In addition, autophagy deficiency increases the activation of p38. The p38 MAPK has a dual role in the regulation of autophagy, as both a positive and negative regulator [51]. Our data show that AG inhibits $\mathrm{p} 38$ phosphorylation. These results are consistent with those of previous studies [52]. Whether the inhibition of p38 phosphorylation by AG can promote the expression of Beclin-1 and LC-3 proteins, and thereby induce autophagy, will be the focus of our next study.

EMT is a process by which cells differentiate from an epithelial to a mesenchymal phenotype [53], and plays an essential role in promoting tumor invasion and metastasis. Although OS originates from mesenchymal cells, mounting evidence suggests that EMT is associated with OS, particularly metastatic OS $[54,55]$. Therefore, controlling the EMT process is regarded as a promising strategy to suppress the metastasis and invasion ability of tumors and improve the survival rate of patients. Until now, the ability of AG to reverse EMT, and the potential mechanisms of its anti-OS activity, remained undiscovered. Our findings suggest that AG is involved in the regulation of the EMT process. Epithelial-related markers are highly expressed with treatment, while the levels of mesenchymal markers decrease. Meanwhile, pivotal factors promoting EMT, such as Snail, are remarkably suppressed. However, the underlying autophagic mechanisms that suppress EMT in OS remain a mystery. The addition of Beclin-1 siRNA to inhibit AG-induced autophagy reversed the inhibitory effect of AG on EMT. Through a series of invasion and metastasis experiments, we found that AG can inhibit the invasion and metastasis of OS, and this effect can be reversed by Beclin-1 siRNA in U-2OS cells. 


\section{Cellular Physiology Cell Physiol Biochem 2017;44:1396-1410 \begin{tabular}{l|l|l} 
and Biochemistry Published online: November 30, 2017 & $\begin{array}{l}\text { (c) } 2017 \text { The Author(s). Published by S. Karger AG, Basel } \\
\text { www.karger.com/cpb }\end{array}$ \\
\hline
\end{tabular}}

Liu et al.: Andrographolide Induces Autophagy in Osteosarcoma Cells

\section{Conclusion}

In the present study, our results reveal that AG inhibits cell viability and induces autophagic cell death in OS cells by suppressing the PI3K/Akt/mTOR pathway and enhancing the JNK pathway. AG-induced autophagy also inhibits the invasion and metastasis of OS cells. These results suggest that AG may represent a promising novel targeted agent in the prevention and treatment of OS. Further investigation of AG in mouse models will contribute to the understanding of its in vivo activity against malignant cells.

\section{Acknowledgements}

This work was supported by the Youth Science Foundation of Heilongjiang Province (Contract grant number: QC2016111to X.Y); China Postdoctoral Sciences Foundation Funded Project: (Contract grant number: 2016M591557 to X.Y); Postdoctoral Foundation of Heilongjiang Province (Contract grant number:LBH-Z16241 to X.Y)

\section{Disclosure Statement}

The authors declare no Disclosure Statement in relation to this article.

\section{References}

$>1$ Seibel NL, Krailo M, Chen Z, Healey J, Breitfeld PP, Drachtman R, Greffe B, Nachman J, Nadel H, Sato JK, Meyers PA, Reaman GH: Upfront window trial of topotecan in previously untreated children and adolescents with poor prognosis metastatic osteosarcoma: children's Cancer Group (CCG) 7943 Cancer 2007;109:1646-1653.

-2 Ayan I, Kebudi R, Ozger H: Childhood osteosarcoma: multimodal therapy in a single-institution Turkish series. Cancer Treat Res 2009;152:319-338.

-3 Faisham WI, Mat Saad AZ, Alsaigh LN, Nor Azman MZ, Kamarul Imran M, Biswal BM, Bhavaraju VM, Salzihan MS, Hasnan J, Ezane AM, Ariffin N, Norsarwany M, Ziyadi MG, Wan Azman WS, Halim AS, Zulmi W: Prognostic factors and survival rate of osteosarcoma: A single-institution study. Asia Pac J Clin Oncol 2017;13:e104-e110.

-4 Hsu YH, Hsu YL, Liu SH, Liao HC, Lee PX, Lin CH, Lo LC, Fu SL: Development of a Bifunctional Andrographolide-Based Chemical Probe for Pharmacological Study. PLoS One 2016;11:e0152770.

-5 Wang Z, Yu P, Zhang G, Xu L, Wang D, Wang L, Zeng X, Wang Y: Design, synthesis and antibacterial activity of novel andrographolide derivatives. Bioorg Med Chem 2010;18:4269-4274.

-6 Abu-Ghefreh AA, Canatan H, Ezeamuzie CI: In vitro and in vivo anti-inflammatory effects of andrographolide. Int Immunopharmacol 2009;9:313-318.

7 Chen JX, Xue HJ, Ye WC, Fang BH, Liu YH, Yuan SH, Yu P, Wang YQ: Activity of andrographolide and its derivatives against influenza virus in vivo and in vitro. Biol Pharm Bull 2009;32:1385-1391.

-8 Zhao F, He EQ, Wang L, Liu K: Anti-tumor activities of andrographolide, a diterpene from Andrographis paniculata, by inducing apoptosis and inhibiting VEGF level. J Asian Nat Prod Res 2008;10:467-473.

9 Chao HP, Kuo CD, Chiu JH, Fu SL: Andrographolide exhibits anti-invasive activity against colon cancer cells via inhibition of MMP2 activity. Planta Med 2010;76:1827-1833.

10 Luo W, Liu Y, Zhang J, Luo X, Lin C, Guo J: Andrographolide inhibits the activation of NF-kappaB and MMP-9 activity in H3255 lung cancer cells. Exp Ther Med 2013;6:743-746.

11 Zhou J, Ong CN, Hur GM, Shen HM: Inhibition of the JAK-STAT3 pathway by andrographolide enhances chemosensitivity of cancer cells to doxorubicin. Biochem Pharmacol 2010;79:1242-1250.

12 Al-Sadoon MK, Rabah DM, Badr G: Enhanced anticancer efficacy of snake venom combined with silica nanoparticles in a murine model of human multiple myeloma: molecular targets for cell cycle arrest and apoptosis induction. Cell Immunol 2013;284:129-138. 


\section{Cellular Physiology Cell Physiol Biochem 2017;44:1396-1410 \begin{tabular}{l|l|l} 
and Biochemistry Publ: 10.1159/000485536 & $\begin{array}{l}\text { C } 2017 \text { The Author(s). Published by S. Karger AG, Basel } \\
\text { www.karger.com/cpb }\end{array}$
\end{tabular}}

Liu et al.: Andrographolide Induces Autophagy in Osteosarcoma Cells

13 Levine B, Kroemer G: Autophagy in the pathogenesis of disease. Cell 2008;132:27-42.

14 He C, Klionsky DJ: Regulation mechanisms and signaling pathways of autophagy. Annu Rev Genet 2009;43:67-93.

15 Codogno P, Meijer AJ: Autophagy and signaling: their role in cell survival and cell death. Cell Death Differ 2005;12 Suppl 2:1509-1518.

16 Heras-Sandoval D, Perez-Rojas JM, Hernandez-Damian J, Pedraza-Chaverri J: The role of PI3K/AKT/mTOR pathway in the modulation of autophagy and the clearance of protein aggregates in neurodegeneration. Cell Signal 2014;26:2694-2701.

17 Corcelle E, Djerbi N, Mari M, Nebout M, Fiorini C, Fenichel P, Hofman P, Poujeol P, Mograbi B: Control of the autophagy maturation step by the MAPK ERK and p38: lessons from environmental carcinogens. Autophagy 2007;3:57-59.

18 Azad MB, Chen Y, Gibson SB: Regulation of autophagy by reactive oxygen species (ROS): implications for cancer progression and treatment. Antioxid Redox Signal 2009;11:777-790.

19 He ZJ, Zhu FY, Li SS, Zhong L, Tan HY, Wang K: Inhibiting ROS-NF-kappaB-dependent autophagy enhanced brazilin-induced apoptosis in head and neck squamous cell carcinoma. Food Chem Toxicol 2017;101:55-66.

20 Catalano M, D’Alessandro G, Lepore F, Corazzari M, Caldarola S, Valacca C, Faienza F, Esposito V, Limatola C, Cecconi F, Di Bartolomeo S: Autophagy induction impairs migration and invasion by reversing EMT in glioblastoma cells. Mol Oncol 2015;9:1612-1625.

21 Kim KW, Paul P, Qiao J, Lee S, Chung DH: Enhanced autophagy blocks angiogenesis via degradation of gastrin-releasing peptide in neuroblastoma cells. Autophagy 2013;9:1579-1590.

22 Wang L, Yang L, Lu Y, Chen Y, Liu T, Peng Y, Zhou Y, Cao Y, Bi Z, Liu Z, Shan H: Osthole Induces Cell Cycle Arrest and Inhibits Migration and Invasion via PTEN/Akt Pathways in Osteosarcoma. Cell Physiol Biochem 2016;38:2173-2182.

-23 Chen G, Fang T, Huang Z, Qi Y, Du S, Di T, Lei Z, Zhang X, Yan W: MicroRNA-133a Inhibits Osteosarcoma Cells Proliferation and Invasion via Targeting IGF-1R. Cell Physiol Biochem 2016;38:598-608.

-24 Zuo D, Zhou Z, Wang H, Zhang T, Zang J, Yin F, Sun W, Chen J, Duan L, Xu J, Wang Z, Wang C, Lin B, Fu Z, Liao Y, Li S, Sun M, Hua Y, Zheng L, Cai Z: Alternol, a natural compound, exerts an anti-tumour effect on osteosarcoma by modulating of STAT3 and ROS/MAPK signalling pathways. J Cell Mol Med 2017;21:208221.

25 Liao HF, Pan CH, Chou PY, Chen YF, Wu TS, Sheu MJ, Wu CH: Toxicological effects of NCKU-21, a phenanthrene derivative, on cell growth and migration of A549 and CL1-5 human lung adenocarcinoma cells. PLoS One 2017;12:e0185021.

26 Liu R, Fu C, Sun J, Wang X, Geng S, Zou J, Bi Z, Yang C: A New Perspective for Osteosarcoma Therapy: Proteasome Inhibition by MLN9708/2238 Successfully Induces Apoptosis and Cell Cycle Arrest and Attenuates the Invasion Ability of Osteosarcoma Cells in vitro. Cell Physiol Biochem 2017;41:451-465.

27 Shen J, Ma H, Zhang T, Liu H, Yu L, Li G, Li H, Hu M: Magnolol Inhibits the Growth of Non-Small Cell Lung Cancer via Inhibiting Microtubule Polymerization. Cell Physiol Biochem 2017;42:1789-1801.

-28 Yang C, Yang QO, Kong QJ, Yuan W, Ou Yang YP: Parthenolide Induces Reactive Oxygen Species-Mediated Autophagic Cell Death in Human Osteosarcoma Cells. Cell Physiol Biochem 2016;40:146-154.

29 Sukardiman H, Widyawaruyanti A, Sismindari, Zaini NC: Apoptosis inducing effect of andrographolide on TD-47 human breast cancer cell line. Afr J Tradit Complement Altern Med 2007;4:345-351.

30 Banerjee A, Ahmed H, Yang P, Czinn SJ, Blanchard TG: Endoplasmic reticulum stress and IRE-1 signaling cause apoptosis in colon cancer cells in response to andrographolide treatment. Oncotarget 2016;7:4143241444.

-31 Al-Sadoon MK, Abdel-Maksoud MA, Rabah DM, Badr G: Induction of apoptosis and growth arrest in human breast carcinoma cells by a snake (Walterinnesia aegyptia) venom combined with silica nanoparticles: crosstalk between Bcl2 and caspase 3 Cell Physiol Biochem 2012;30:653-665.

-32 Selvakumaran M, Amaravadi RK, Vasilevskaya IA, O’Dwyer PJ: Autophagy inhibition sensitizes colon cancer cells to antiangiogenic and cytotoxic therapy. Clin Cancer Res 2013;19:2995-3007.

-33 Ahn CH, Jeong EG, Lee JW, Kim MS, Kim SH, Kim SS, Yoo NJ, Lee SH: Expression of beclin-1, an autophagyrelated protein, in gastric and colorectal cancers. APMIS 2007;115:1344-1349.

34 Butler DE, Marlein C, Walker HF, Frame FM, Mann VM, Simms MS, Davies BR, Collins AT, Maitland NJ: Inhibition of the PI3K/AKT/mTOR pathway activates autophagy and compensatory Ras/Raf/MEK/ERK signalling in prostate cancer. Oncotarget 2017;8:56698-56713. 


\section{Cellular Physiology Cell Physiol Biochem 2017;44:1396-1410 \begin{tabular}{l|l|l} 
and Biochemistry & DOI: 10.1159/000485536 & (c) 2017 The Author(s). Published by S. Karger AG, Basel \\
www.karger.com/cpb
\end{tabular}

35 Meijer AJ, Codogno P: Regulation and role of autophagy in mammalian cells. Int J Biochem Cell Biol 2004;36:2445-2462.

-36 Jaber N, Dou Z, Chen JS, Catanzaro J, Jiang YP, Ballou LM, Selinger E, Ouyang X, Lin RZ, Zhang J, Zong WX: Class III PI3K Vps34 plays an essential role in autophagy and in heart and liver function. Proc Natl Acad Sci U S A 2012;109:2003-2008.

37 Shimizu S, Konishi A, Nishida Y, Mizuta T, Nishina H, Yamamoto A, Tsujimoto Y: Involvement of JNK in the regulation of autophagic cell death. Oncogene 2010;29:2070-2082.

-38 Wang J, Whiteman MW, Lian H, Wang G, Singh A, Huang D, Denmark T: A non-canonical MEK/ERK signaling pathway regulates autophagy via regulating Beclin 1 J Biol Chem 2009;284:21412-21424.

39 Webber JL, Tooze SA: Coordinated regulation of autophagy by p38alpha MAPK through mAtg9 and p38IP. EMBO J 2010;29:27-40.

40 Lee YC, Lin HH, Hsu CH, Wang CJ, Chiang TA, Chen JH: Inhibitory effects of andrographolide on migration and invasion in human non-small cell lung cancer A549 cells via down-regulation of PI3K/Akt signaling pathway. Eur J Pharmacol 2010;632:23-32.

41 Tu YS, Sun DM, Zhang JJ, Jiang ZQ, Chen YX, Zeng XH, Huang DE, Yao N: Preparation and characterisation of andrographolide niosomes and its anti-hepatocellular carcinoma activity. J Microencapsul 2014;31:307316.

42 Kumar S, Patil HS, Sharma P, Kumar D, Dasari S, Puranik VG, Thulasiram HV, Kundu GC: Andrographolide inhibits osteopontin expression and breast tumor growth through down regulation of PI3 kinase/Akt signaling pathway. Curr Mol Med 2012;12:952-966.

43 Banerjee A, Banerjee V, Czinn S, Blanchard T: Increased reactive oxygen species levels cause ER stress and cytotoxicity in andrographolide treated colon cancer cells. Oncotarget 2017;8:26142-26153.

44 Li GD, Wu DQ Li BY: [Research progresses on the role of cell autophagy in cancer]. Ai Zheng 2009;28:445448.

-45 Sun Y, Liu JH, Jin L, Lin SM, Yang Y, Sui YX, Shi H: Over-expression of the Beclin1 gene upregulates chemosensitivity to anti-cancer drugs by enhancing therapy-induced apoptosis in cervix squamous carcinoma CaSki cells. Cancer Lett 2010;294:204-210.

-46 Qiang L, He YY: Autophagy deficiency stabilizes TWIST1 to promote epithelial-mesenchymal transition. Autophagy 2014;10:1864-1865.

47 Jin S, White E: Role of autophagy in cancer: management of metabolic stress. Autophagy 2007;3:28-31.

48 Fekadu J, Rami A: Beclin-1 Deficiency Alters Autophagosome Formation, Lysosome Biogenesis and Enhances Neuronal Vulnerability of HT22 Hippocampal Cells. Mol Neurobiol 2016;53:5500-5509.

49 Rosenfeldt MT, Ryan KM: The multiple roles of autophagy in cancer. Carcinogenesis 2011;32:955-963.

50 Wu YT, Tan HL, Shui G, Bauvy C, Huang Q Wenk MR, Ong CN, Codogno P, Shen HM: Dual role of 3-methyladenine in modulation of autophagy via different temporal patterns of inhibition on class I and III phosphoinositide 3-kinase. J Biol Chem 2010;285:10850-10861.

51 Sui X, Kong N, Ye L, Han W, Zhou J, Zhang Q, He C, Pan H: p38 and JNK MAPK pathways control the balance of apoptosis and autophagy in response to chemotherapeutic agents. Cancer Lett 2014;344:174-179.

52 Hsieh MJ, Lin CW, Chiou HL, Yang SF, Chen MK: Dehydroandrographolide, an iNOS inhibitor, extracted from Andrographis paniculata (Burm.f.) Nees, induces autophagy in human oral cancer cells. Oncotarget 2015;6:30831-30849.

-53 Micalizzi DS, Ford HL: Epithelial-mesenchymal transition in development and cancer. Future Oncol 2009;5:1129-1143.

54 Shang Y, Li Z, Li H, Xia H, Lin Z: TIM-3 expression in human osteosarcoma: Correlation with the expression of epithelial-mesenchymal transition-specific biomarkers. Oncol Lett 2013;6:490-494.

55 Yu L, Liu S, Guo W, Zhang C, Zhang B, Yan H, Wu Z: hTERT promoter activity identifies osteosarcoma cells with increased EMT characteristics. Oncol Lett 2014;7:239-244. 